\title{
HAJI DAN UMRAH
}

\author{
Muhammad Noor \\ Jurusan Teknik Informatika, Politeknik Negeri Tanah Laut \\ e-mail: muhammadnoorpolitala@gmail.com
}

\begin{abstract}
Abstrak
Haji dan umrah, adalah kewajiban bagi setiap muslim yang berakal dan memiliki kemampuan, namun dari kalangan umum seperti petani, pedagang, pegawai negeri bahkan para pengusaha sukses pun masih ada yang belum mengerti tentang tata cara melaksanakan Haji dan umrah yang sesuai dengan tuntunan syariat Islam. Berdasarkan permasalahan tersebut penulis merasa penting untuk menulis tentang Haji dan Umroh agar bisa melaksanakan ibadah tersebut dengan baik dan benar menurut syari'at islam. Penulis menjelaskan tentang Rukun, Syarat, wajib Haji, serta sunnah-sunnah yang terdapat dalam ibadah Haji dan Umroh.
\end{abstract}

\section{Kata Kunci: Tata cara, Syari’at Islam}

\begin{abstract}
Haji and Umrah, is an obligation for every Muslim who has reason and has the ability, but from the general public such as farmers, traders, civil servants and even successful entrepreneurs there are still those who do not understand the procedures for carrying out Hajj and Umrah according to the guidelines of Islamic law. Based on these problems the author feels it is important to write about Hajj and Umrah in order to carry out the worship properly and correctly according to the Islamic Shari'ah. The author explains about Pillars, Terms, mandatory Hajj, and the Sunnah that are found in Hajj and Umrah worship.
\end{abstract}

Keywords: Procedures, Shari'at Islam

\section{PENDAHULUAN}

Agama Islam bertugas mendidik dzahir manusia, mensucikan jiwa manusia, dan membebaskan diri manusia dari hawa nafsu. Dengan ibadah yang tulus ikhlas dan aqidah yang murni sesuai kehendak Allah, insya Allah akan menjadi orang yang beruntung. Ibadah dalam agama Islam banyak macamnya. Haji dan umroh adalah salah satunya. Haji merupakan rukun iman yang kelima setelah syahadat, sholat, zakat, dan puasa. Ibadah haji adalah ibadah yang baik karena tidak hanya menahan hawa nafsu dan menggunakan tenaga dalam mengerjakannya, namun juga semangat dan harta (Zarkasyi, 1995).

Rukun Islam yang terakhir adalah naik haji ke Baitullah. Maksudnya adalah berkunjung ke tanah suci (Baitullah) untuk melaksanakan serangkaian amal ibadah sesuai dengan syarat, rukun, dan waktu yang telah ditentukan. Ibadah haji ditentukan kepada muslim yang mampu. Pengertian mampu atau kuasa yaitu mempunyai bekal yang cukup untuk pergi dan bekal bagi keluarga yang ditinggalkannya. Sama halnya dengan umrah yang dapat dilakukan pada bulan- bulan lain selain bulan Zulhijah. Haji dan umrah merupakan suatu kegiatan rohani yang di dalamnya terdapat pengorbanan, ungkapan rasa syukur, berbuat kebajikan dengan kerelaan hati, melaksanakan perintah Allah, serta mewujud-kan pertemuan besar dengan umat Islam lainnya di seluruh dunia. Firman Allah swt. Surah A1 Baqarah Ayat 125 (Aziz dan Hawwas, 2001:482). 
Dalam mengerjakan haji, diperlukan penem-puhan jarak yang demikian jauh untuk men-capai Baitullah, dengan segala kesukaran dan kesulitan dalam perjalanan, berpisah dengan sanak keluarga hanya dengan satu tujuan untuk mencapai kepuasan batin dan kenikmatan rohani (Sulaiman, 2001:324).

Haji dan Umrah, adalah kewajiban bagi setiap muslim yang berakal dan memiliki kemampuan, namun dari kalangan umum seperti petani, pedagang, pegawai negeri bahkan para pengusaha sukses pun masih ada yang belum mengerti tentang Haji dan Umrah (Rasyied, 2003).

\section{PEMBAHASAN}

Secara bahasa Haji adalah menuju ke suatu tempat secara berulang-ulang, atau menuju ke suatu tempat yang dimuliakan atau diagungkan oleh suatu kaum peradaban. Ibadah umat Islam ke Mekkah (Baitullah) inilah yang disebut Haji. Sebab Baitullah adalah tempat yang diagungkan dan tempat yang suci bagi umat Islam. Adapun menurut istilah, kalangan ahli fiqh mengartikan bahwa Haji adalah niatan datang ke Baitullah untuk menunaikan ritual ibadah tertentu. Ibnu Al-Humam mengartikan bahwa Haji adalah pergi menuju Baitul Haram untuk menunaikan aktivitas tertentu pada waktu tertentu. Para ahli fiqh lainnya juga berpendapat bahwa Haji adalah mengunjungi tempat-tempat tertentu dengan perilaku tertentu pada waktu tertentu (Azzi dan Hawwas, 2001:148).

Penetapan waktu Haji sendiri ada kalangan yang berpendapat bahwa Haji diwajibkan pada tahun $5 \mathrm{H}$, namun ada yang mengungkapkan lain yaitu: tahun $8 \mathrm{H}, 9 \mathrm{H}$ bahkan ada yang berpen-dapat jauh sebelum tahun Hijriah. Namun Nabi Muhammad s.a.w. baru menunaikan ibadah Haji pada tahun $10 \mathrm{H}$ sebab pada tahun $7 \mathrm{H}$ beliau keluar ke Mekkah untuk menunaikan dan tidak berhaji (Ibid, 2002:486).

Adapun umrah menurut bahasa bermakna 'ziarah'. Sedangkan menurut syara' umrah ialah menziarahi ka'bah, melakukan tawaf di se-kelilingnya, bersa'i antara Shafa dan Marwah dan mencukur atau menggunting rambut dengan cara tertentu dan dapat dilaksanakan setiap waktu (Aziz dan Hawwas, 2001:297).

\section{Hukum Mengerjakan Ibadah Haji}

Hukum melaksanakan haji adalah wajib bagi setiap muslim yang mampu, sesuai dengan firman Allah dalam Surah Ali Imran Ayat 97. Ibadah haji, fardhu adalah sesuatu yang apabila tidak dikerjakan sesuai ketentuannya, maka ibadah haji tidak sah; seperti tidak melakukan wukuf di 'Arafah. Wajib dalam ibadah haji atau umrah adalah sesuatu yang jika diabaikan secara keseluruhan, atau tidak memenuhi sya-ratnya maka haji atau umrah tetap sah, tetapi orang yang bersangkutan harus melaksanakan sanksi yang telah ditetapkan. Misalnya, kewa-jiban melempar jumroh, bila ia diabaikan, maka ia harus diganti dengan membayar dam (denda). Sesuatu yang sunnah bila dilakukan, atau sesuatu yang makruh, jika ditinggalkan dapat mendukung kesempurnaan ibadah haji dan umrah. Sedang sesuatu yang mubah, tidak berdampak apa pun terhadap ibadah. Sedangkan umrah hukumnya mutahabah artinya baik untuk dilakukan dan tidak diwajibkan atau disebut tatawwu, yang artinya ialah tidak diwajibkan, tetapi baik dilakukan untuk mendekatkan diri kepada Allah dan melakukannya lebih utama dari pada meninggalkannya karena tatawwu mempunyai ganjaran pahala (Mizan, 2000:157-158).

\section{Syarat-syarat Wajib Haji dan Umroh}

Orang-orang yang wajib menjalankan haji dan Umroh itu hanyalah yang memenuhi syarat-syarat yaitu: Islam (beragama Islam merupa-kan syarat mutlak bagi orang yang akan melaksanakan ibadah haji dan umrah. Karena itu orang-orang kafir tidak mempunyai kewa-jiban haji dan umrah. Demikian pula orang yang murtad), berakal (yaitu wajib bagi orang yang bisa membedakan yang mana kebaikan dan yang mana keburukan), baligh 
(bagi laki-laki yaitu sudah pernah berimpi basah atau umur lebih 15 tahun dan bagi perempuan sudah keluar darah haid. Anak kecil tidak wajib haji dan umrah. Sebagaimana dikatakan oleh nabi Muhammad s.a.w. "Kalam dibebaskan dari mencatat atas anak kecil sampai ia menjadi baligh, orang tidur sampai ia bangun, dan orang yang gila sampai ia sembuh"), merdeka (yaitu tidak menjadi budak orang lain. Budak tidak wajib melakukan ibadah haji karena ia bertugas melakukan kewajiban yang dibebankan oleh tuannya. Padahal menunaikan ibadah haji memerlukan waktu. D isamping itu budak itu termasuk orang yang tidak mampu dari segi biaya, waktu dan lain-lain), mampu atau kuasa (artinya yaitu mampu dalam perjalanan, mampu harta, dan mampu badan atau sehat jasmani dan rohani) (Fiqih Islam, 2001:204-205).

\section{Rukun Haji dan Umrah}

Rukun haji adalah kegiatan-kegiatan yang apabila tidak dikerjakan, maka hajinya dianggap batal. Berbeda dengan wajib Haji, wajib Haji adalah suatu perbuatan yang perlu dikerjakan, namun wajib Haji ini tidak menentukan sah nya suatu ibadah haji, apabila wajib haji tidak dikerjakan maka wajib digantinya dengan dam (denda). Rukun haji ada enam, yaitu:

a. Ihram (Berniat)

Ihram adalah berniat mengerjakan Haji atau Umrah bahkan keduanya sekaligus, Ihram wajib dimulai miqatnya, baik miqat zamani maupun miqat makani. Sunnah sebelum memulai ihram diantarnya adalah mandi, menggunakan wewangian pada tubuh dan rambut, mencukur kumis dan memotong kuku. Untuk pakaian ihram bagi laki-laki dan perempuan berbeda, untuk laki-laki berupa pakaian yang tidak dijahit dan tidak bertutup kepala, sedangkan perempuan seperti halnya shalat (tertutup semua kecuali muka dan telapak tangan).

b. Wukuf (Hadir) di Arafah
Waktu wukuf adalah tanggal 9 dzulhijjah pada waktu dzuhur, setiap seorang yang Haji wajib baginya untuk berada di padang Arafah pada waktu tersebut. Wukuf adalah rukun penting dalam Haji, jika wukuf tidak dilaksanakan dengan alasan apapun, maka Hajinya dinyatakan tidak sah dan harus diulang pada waktu berikutnya. Pada waktu wukuf disunnah-kan untuk memperbanyak istighfar, zikir, dan doa untuk kepentingan diri sendiri maupun orang banyak, dengan mengangkat kedua tangan dan menghadap kiblat.

c. Tawaf Ifadah

Tawaf ifadah adalah mengelilingi Kakbah sebanyak 7 kali dengan syarat: suci dari hadas dan najis baik badan maupun pakaian, menutup aurat, kakbah berada di sebelah kiri orang yang mengelilinginya, memulai tawaf dari arah hajar aswad (batu hitam) yang terletak di salah satu pojok di luar Kakbah. Macam-macam tawaf itu sendiri ada lima macam yaitu:

1) Tawaf qudum adalah tawaf yang dilakukan ketika baru sampai di Mekah.

2) Tawaf ifadah adalah tawaf yang menjadi rukun haji.

3) Tawaf sunah adalah tawaf yang dilakukan semata-mata mencari rida Allah.

4) Tawaf nazar adalah tawaf yang dilakukan untuk memenuhi nazar.

5) Tawaf wada adalah tawaf yang dilakukan sebelum meninggalkan kota Mekah

d. Sa'i

Sa'i adalah lari-lari kecil atau jalan cepat antara Safa dan Marwa (keterangan lihat QS Al Baqarah: 158). Syarat-syarat sa'i adalah sebagai berikut.

1) Dimulai dari bukit Safa dan berakhir di bukit Marwa.

2) Dilakukan sebanyak tujuh kali.

3) Melakukan sa'i setelah tawaf qudum.

e. Tahalul

Tahalul adalah mencukur atau menggunting rambut sedikitnya tiga helai. Pihak yang menga-takan bercukur sebagai rukun haji, 
beralasan karena tidak dapat diganti dengan penyem-belihan.

\section{f. Tertib.}

Tertib maksudnya menjalankan rukun haji secara berurutan (Aziz dan Hawwas, 2001:278-301)

\section{Wajib Haji}

Amalan dalam ibadah Haji yang wajib dikerjakan disebut wajib Haji. Wajib Haji tidak menentukan sahnya ibadah haji. Jika tidak dikerjakan Haji tetap sah, namun dikenakan dam (denda).

Berikut adalah beberapa wajib haji, yaitu:

a. Ihram dari Miqat

Miqat adalah tempat dan waktu yang disediakan untuk melaksanakan ibadah Haji. Ihram dari Miqat bermaksud niat Haji ataupun niat Umrah dari miqat, baik miqat zamani maupun miqat makani.

Miqat makani adalah tempat awal melaksanakan ihram bagi yang akan Haji dan Umrah.

b. Bermalam di Muzdalifah

Dilakukan sesudah wukuf di Arafah (sesudah terbenamnya matahari) pada tanggal 9 dzulhijjah. Di Muzdalifah melaksanakan sholat Maghrib dan Isya' melakukan jamak dan qasar karena suatu perjalanan jauh. Di Muzdalifah inilah kita dapat mengambil kerikil-kerikil untuk melaksanakan Wajib Haji selanjutnya (melempar Jumrah) kita bisa mengambil sebanyak 49 atau 70 butir kerikil.

c. Melempar Jumrah 'aqabah

Pada tanggal 10 Dzulhijjah di Mina dilaksanakannya melempar jumrah sebanyak tujuh butir kerikil sebanyak tujuh kali lemparan. Waktu paling utama untuk melempar jumrah ini yaitu waktu Dhuha, setelah melakukan ini kemudian melaksanakan tahalul pertama (mencukur atau memotong rambut).

d. Melempar Jumrah ula, wustha, dan 'aqabah Melempar ketiga jumrah ini dilaksanakan pada tanggal 11, 12, dan 13 Dzulhijjah, diuatamakan sesudah tergelincirnya matahari. Dalam hal ini ada yang melaksanakan hanya pada tanggal 11 dan 12 saja kemudian ia kembali ke Mekkah, inilah yang disebut dengan nafar awal. Selain nafar awal ada juga yang dissebut nafar sani, yaitu orang yang baru datang pada tangal 13 Dzulhijjah nya, orang-orang ini diharuskan melempar jumrah tiga sekaligus, yang masing-masing tujuh kali lemparan.

e. Bermalam di Mina

Pada tanggal 11-1 Dzulhijjah ini lah yang diwajibkan bermalam di Mina. bagi yang nafar awal diperbolehkan hanya bermalam pada tanggal 11-12 saja.

f. Thawaf wada'

Sama dengan Thawaf sebelumnya, Thawaf wada' dilakukan disaat akan meninggalkan Baitullah Makkah.

g. Menjauhkan diri dari hal yang di haramkan pada saat ihram.

Menghindari dari berbagai larangan yang sudah ditentukan karena orang-orang yang melanggar aturan ini akan dikenakan dam atau denda (Aziz dan Hawwas, 2001:307332).

\section{Sunnah-sunnah Haji}

Cukup banyak sunnah-sunnah haji. Diantara berikut ini adalah sunnah-sunnah yang berhubungan dengan ihram, thawaf, sa'i, dan wukuf, yaitu:

1. Mandi sebelum ihram

2. Menggunakan kain ihram yang baru

3. Memperbanyak talbiyah

4. Melakukan thawaf qudum (kedatangan)

5. Shalat dua rakaat thawaf

6. Bermalam di Mina

7. Mengambil pola ifrad, yaitu pola mendahulukan Haji daripada Umrah

8. Thawaf wada' (perpisahan) (Salim, 2007)

\section{Larangan Selama Berihram Haji}

Hal-hal yang dimaksud larangan ini adalah yang diharamkan dilakukan bagi yang berihram, haram bukan artian sebagai perbuatan yang menjadikan dosa, karena belum pernah ada pendapat ulama tentang pelanggar lara- 
ngan-larangan ini mendapatkan dosa. Sebagai contoh pelanggaran suatu hajat, tidak mencukur rambut dikarenakan memiliki penyakit yang jika rambutnya dicukur bisa mengurangi kese-hatan seorang haji, maka ini hukumnya tidak dosa. Adapun jika larangan ini sengaja di-langgar maka ia akan berdosa.

Beberapa larangan tersebut diantaranya, yaitu:

1. Bagi laki-laki dilarang menggunakan pakaian berjahit.

2. Bagi laki-laki dilarang menggunakan penutup kepala.

3. Larangan bagi perempuan untuk menutup muka dan telapak tangganya.

4. Di saat ihram bagi laki-laki maupun perempuan wangi-wangian untuk badan maupun pakaian, boleh memakainya sebelum ihram.

5. Dilarang menikah, menikahkan, ataupun menjadi wali nikah. Tidak boleh ada proses pernikahan.

6. Dilarang bersetubuh (senggama) (Uwaydah, 2008).

\section{KESIMPULAN}

Masalah pelaksanaan Haji dan Umroh adalah masalah yang penting, karena termasuk dari bagian rukun Islam yang ke lima. Pelaksaan ibadah Haji dan Umroh haruslah sesuai dengan tata cara yang telah diatur dalam syari'at Islam dalam hal ini seseorang yang ingin melaksanakan ibadah Haji dan Umroh haruslah mengetahui Rukun, Syarat, sesuatu yang diwajibkan dalam Ibadah Haji dan Umroh serta kesunnahan-kesunnahannya.

\section{DAFTAR PUSTAKA}

Abu Malik Kamal bin Sayyid Salim, Fiqih Sunah untuk Wanita, (Jakarta: Al-Ptishom Cahaya Umat, 2007)

Departemen Agama Islam, Pendidikan Agama Islam ,(Jakarta: Departemen Agama, 2001), Cet 9 .

Sayyed Hawwas, Fiqh Ibadah,(Jakarta: Sinar Grafika Offset, 2009)
Saleb Al-Fauzan, Fiqh sehari-hari,(Jakarta: Gema Insani, 2009) Cet 2.

Syaikh Karnil Muhammad Uwaidah, Fikih Wanita, (Jakarta: Pustaka Al-Kautsar, 2008)

Zarkasyi, Imam.1995.Pelajaran Fiqih 2. Ponorogo:Trimurti Press 